CASE REPORT

\title{
Diagnosis and Treatment of Three Cases of Bronchial Carcinoma In Situ
}

\author{
Valeri Y. Andreev ${ }^{1}$, Nikolay A. Yanev ${ }^{1}$, Stefan K. Stanimirov ${ }^{1}$, Temenuzhka V. Mircheva², \\ Ivan N. Ivanov ${ }^{2}$, Savelina Popovska ${ }^{2}$, Petkana A. Hristova ${ }^{3}$, Yavor Y. Ivanov ${ }^{1}$ \\ ${ }^{1}$ Clinic of Pneumonology and Phthisiatry, Dr. G. Stranski University Hospital, Pleven, Bulgaria \\ 2 Department of Pathological Anatomy, Dr. G. Stranski University Hospital, Pleven, Bulgaria \\ ${ }^{3}$ Department of Social and Preventive Medicine, Medical Statistics, Pedagogics and Psychology, Medical University of Pleven, \\ Pleven, Bulgaria
}

\section{Correspondence:}

Yavor Y. Ivanov, Clinic of Pneumonology and Phthisiatry, Dr. G. Stranski University Hospital, Pleven, 91 Vladimir Vazov Str., 5800 Pleven, Bulgaria

E mail:pulmovan@gmail.com Tel: +359887740377

Received: 29 Dec 2016

Accepted: 30 May 2017

Published Online: 23 June 2017

Published: 30 March 2018

Key words: autofluorescence bronchoscopy, carcinoma in situ

Citation: Andreev VY, Yanev NA, Stanimirov SK, Mircheva TV, Ivanov IN, Popovska S, Hristova PA, Ivanov YY. Diagnosis and treatment of three cases of bronchial carcinoma in situ. Folia Med (Plovdiv) 2018;60(1):164-9.

doi: 10.1515/folmed-2017-0062
As part of a retrospective study on bronchoscopies performed at the Clinic of Pneumonology and Phthisiatry of the University Hospital - Pleven by autofluorescence bronchoscopy we found 3 cases diagnosed with carcinoma in situ. They were treated in different ways - endobronchial electrocoagulation, extraction by forceps biopsy and open surgery, but the result was the same - clinical healing. The paper presents the three clinical cases and the analysis of the treatment.

\section{INTRODUCTION}

The bronchial lesion reported histologically as 'carcinoma in situ' (CIS) is challenging because it is mandatory to decide what kind of treatment should be administered. The choice lies between a follow-up approach in the case of endobronchial dysplasia and an aggressive approach if the lesion is defined as invasive carcinoma. We present three patients with CIS where the treatment was different but the end was successful.

\section{CASE REPORT}

CASE 1

A 70-year-old man was admitted to the clinic with complaints of bloody sputum after symptoms of $\mathrm{flu}$. He was laryngectomized because of carcinoma of the larynx and had permanent tracheostomy. He was a heavy smoker (80 pack years) and had an occupational exposure to pesticides. Physical examination was unremarkable. On the chest X-ray there were pulmonary emphysema and calcifications in the left lung and pleural cavity (Fig. 1). Videobronchoscopy revealed that the minimal bleeding source is the eperon between the left B10a and B10b. The forceps biopsy tissue found bronchial mucosa with high grade dysplasia and a piece of squamous type lung cancer (Fig. 2). The chest computer tomography (CT) did not find any signs of tumor at the specified site. The patient declined surgery and an endobronchial electrocoagulation was performed with autofluorescence videobronchoscope Olympus Lucera CV 260SL and a generator of electricity Olympus PSD-20. The procedure was done using a $5 \mathrm{~W}$ electrocatheter. The result was complete coagulation of the neoplastic lesion and appearance of fluorescence positive scar (Figs 3, 4). These conditions were checked-up three 


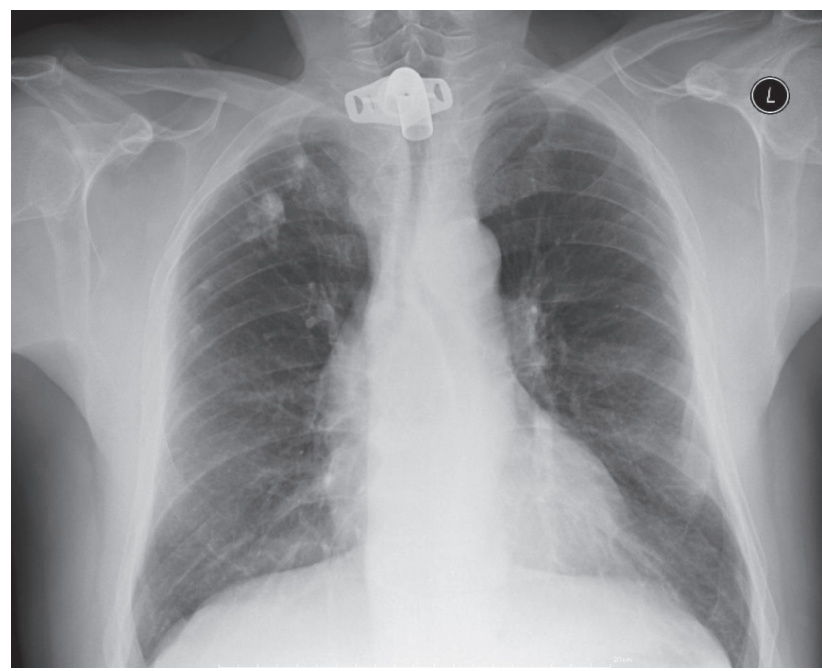

Figure 1. Posterior-anterior chest X-ray of case 1 patient.

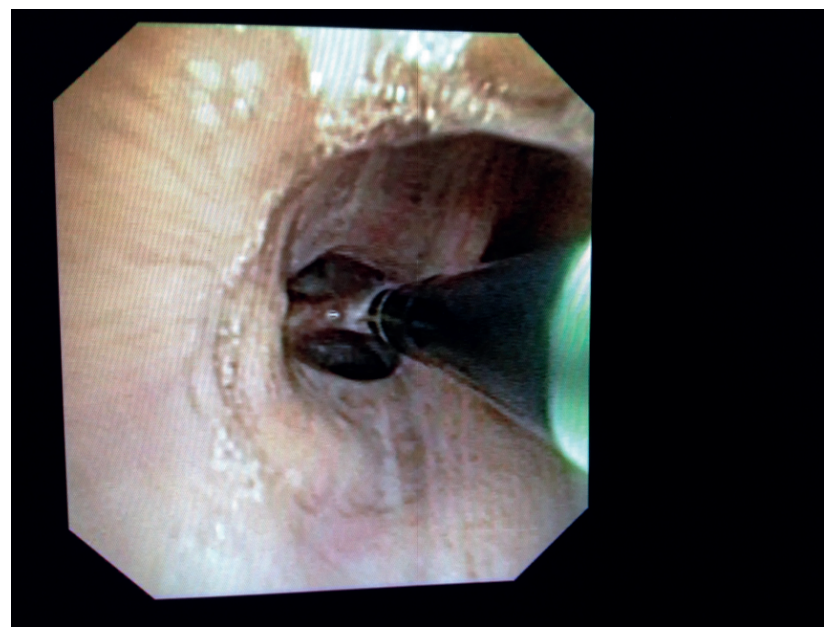

Figure 3. White light bronchoscopy. Endobronchial electrocautery applied to the lesion.

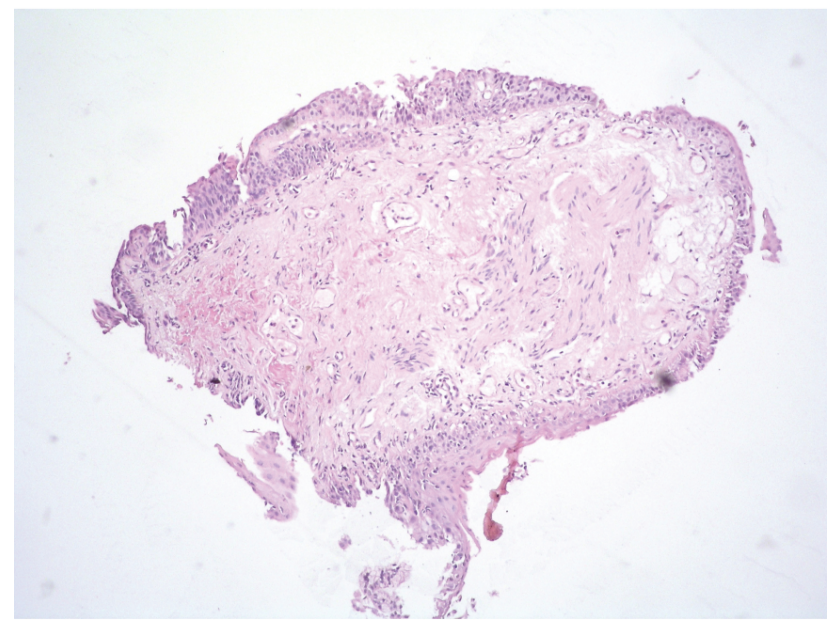

Figure 5. HE, 100X. Squamous epithelium, fibroepithelial polyp, thermal changes.

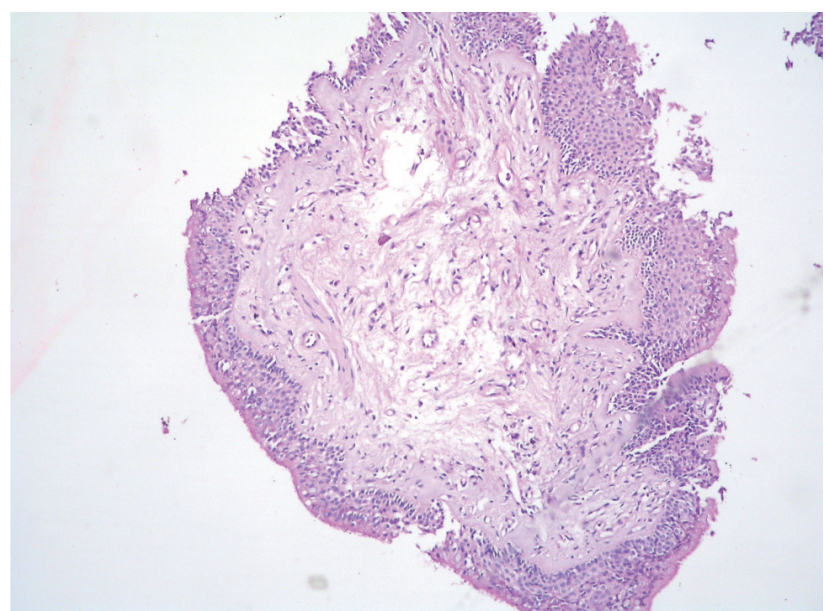

Figure 2. HE, 100X. Severe dysplasia, parenchyma infiltrated by tumor, non-small cell lung cancer, p63 /+/, squamous cell cancer.

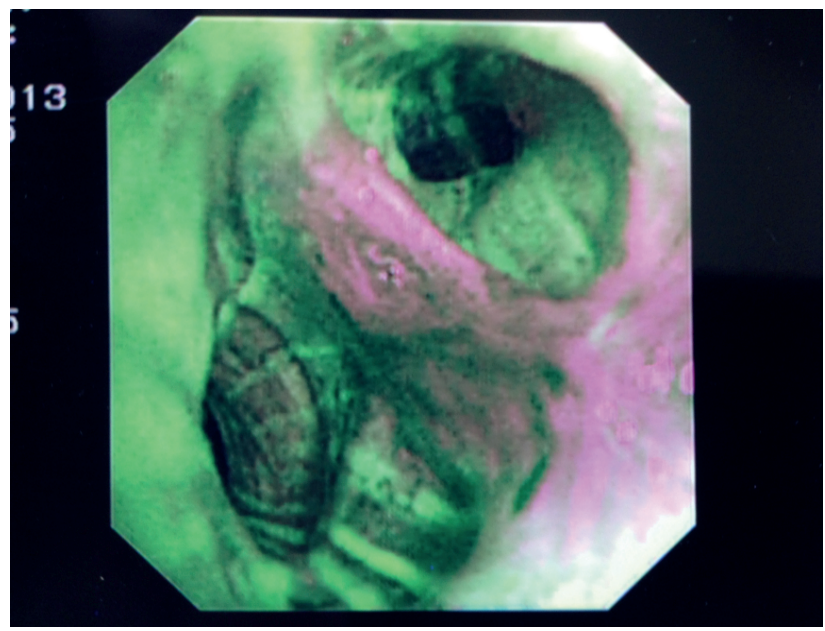

Figure 4. Autofluorescence bronchoscopy. A scar after electrocautery.

times by bronchoscopy and biopsies during the following 8 months. The histological results showed fibrotic polyp (Fig. 5). Next bronchoscopy revealed bleeding from the main carina and the place was biopsied. Histology showed high grade dysplasia.

\section{CASE 2}

A 58-year-old man was admitted with complaints of pain in the left shoulder for 10 days, high temperature up to $38^{\circ} \mathrm{C}$, sweating and cough. He was treated at home with levofloxacin with slight effect. Because of COPD he had permanent treatment with symbicort and seebri. He was a smoker, 40 pack years. He had worked in companies producing cement and aluminium. Physical examination showed wheezing and rales at the bottom of both 
lungs. Oxygen saturation was $96 \%$ and FEV1 $33 \%$ predicted value. The chest $X$ - ray showed pulmonary emphysema (Fig. 6). Bronchoscopy found bleeding infiltration at the eperon between left B1 and B2 (Fig. 7). Forceps biopsy histology showed a piece of bronchial wall with high grade dysplasia

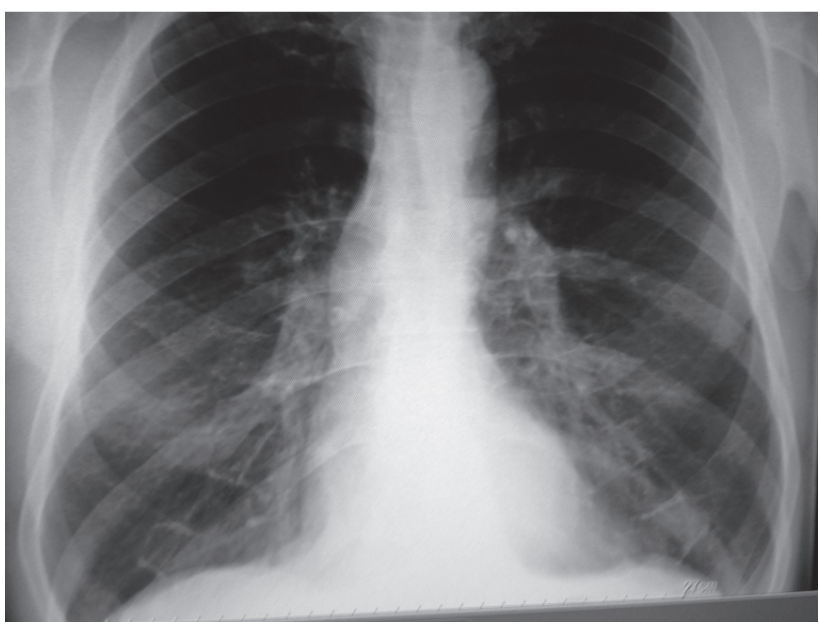

Figure 6. Posterior-anterior chest X-ray of case 2 patient.

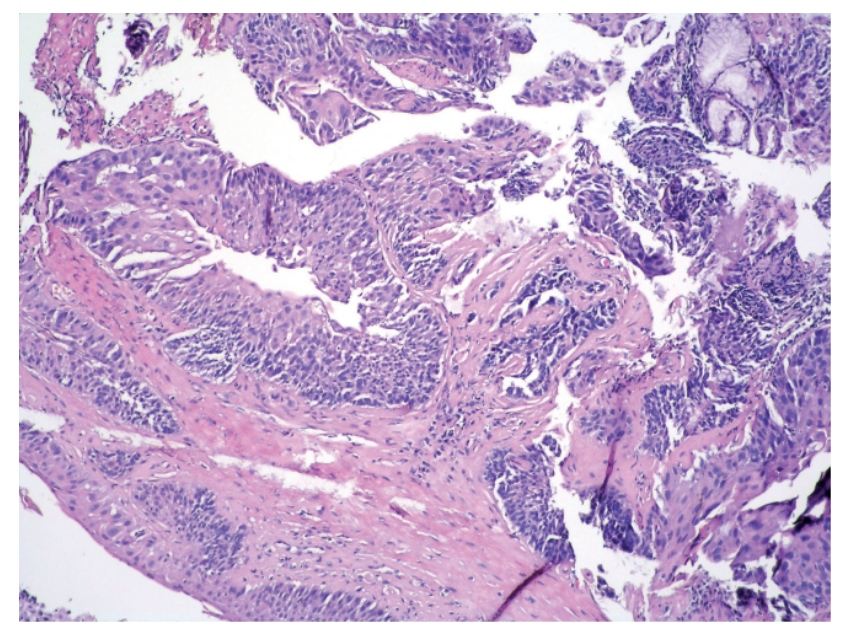

Figure 8. HE, 100X. Bronchial wall with severe dysplasia and carcinoma in situ and invasive squamous cancer. Endobronchial forceps biopsy.

to carcinoma in situ and invasive carcinoma (Fig. 8). After two months the patient underwent open surgery and his left upper lobe was removed. The histological result from the surgery specimen showed only one place with neoplastic changes. Against the background of squamous metaplasia, invasive squamous carcinoma was found with focal keratinization and invasion in the submucosa (Fig. 9).

\section{CASE 3}

A 64-year-old man was admitted to the clinic with complaints of fever, sweating, cough, and bloody sputum. He had myocardial infarction in the past and currently - ischemic coronary disease and COPD.

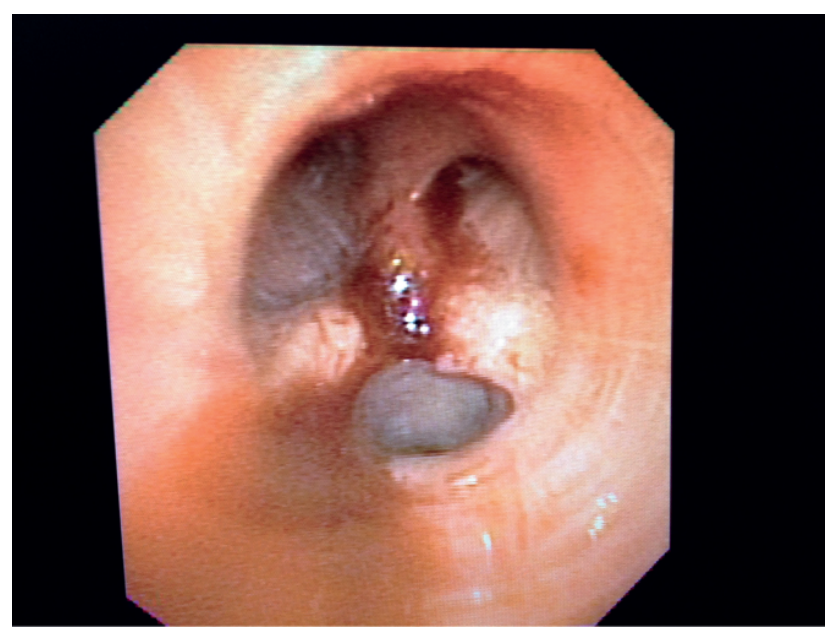

Figure 7. White light bronchoscopy. Bleeding endobronchial lesions in culmen of left lung.

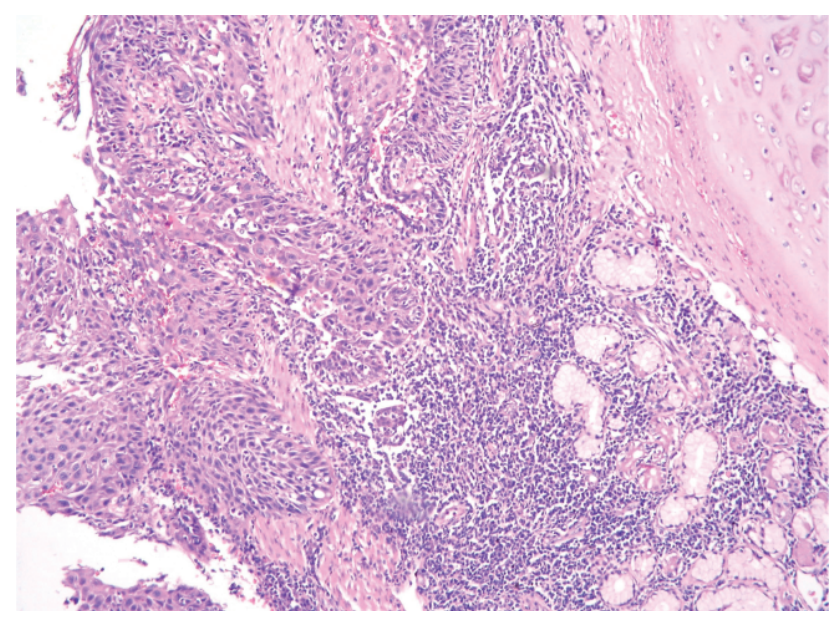

Figure 9. HE, 100X. Against the background of incomplete squamous metaplasia invasive squamous carcinoma is found with focal keratinization and submucosal invasion. Surgical sample.

He was a smoker, 40 pack years. Crackles were found at the lung bases. There were no laboratory signs of inflammatory process. On the chest X-ray there was only reticular pattern in the lower parts of the lungs accepted as bronchiectasis (Fig. 10). The same pattern was found on the chest CT scan.

During bronchoscopy a foreign body was found - a transparent plastic piece partly obstructing the right lower lobe bronchus and the middle lobe 
bronchus (Fig. 11). After removal of the body by extraction with fibroforceps granulation tissue was found along the eperon between the lower lobe and the middle lobe bronchi. It was fuorescence positive and it was removed by forceps. Histological examination showed nests with tumor tissue with characteristics of squamous carcinoma (Fig. 12).

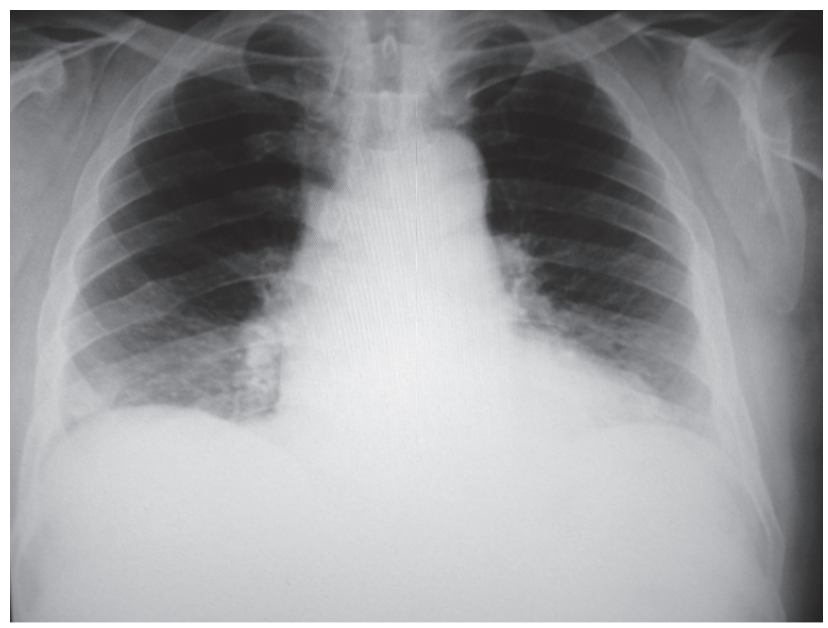

Figure 10. Posterior-anterior chest X-ray of case 3 patient.

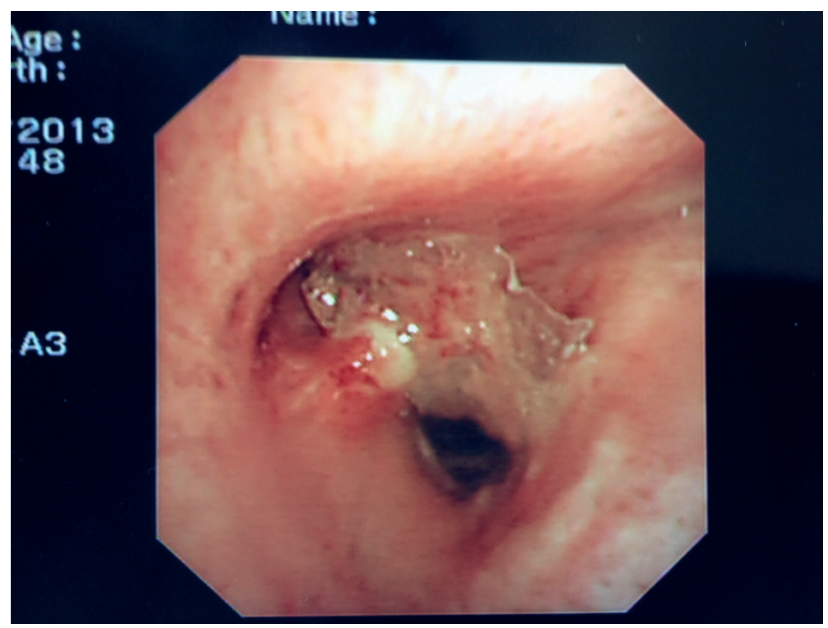

Figure 11. White light bronchoscopy. A foreign body and granulation tissue in middle lobe and lower bronchi.

A control bronchoscopy was performed after one month and fluorescence moderately positive eperon of the middle lobe bronchus was found without other changes (Fig. 13). Forceps biopsy was done again. The result was inflammatory changes of the mucosa (Fig. 14). After 5 months the investigation was repeated and the result was the same - inflammatory changes.

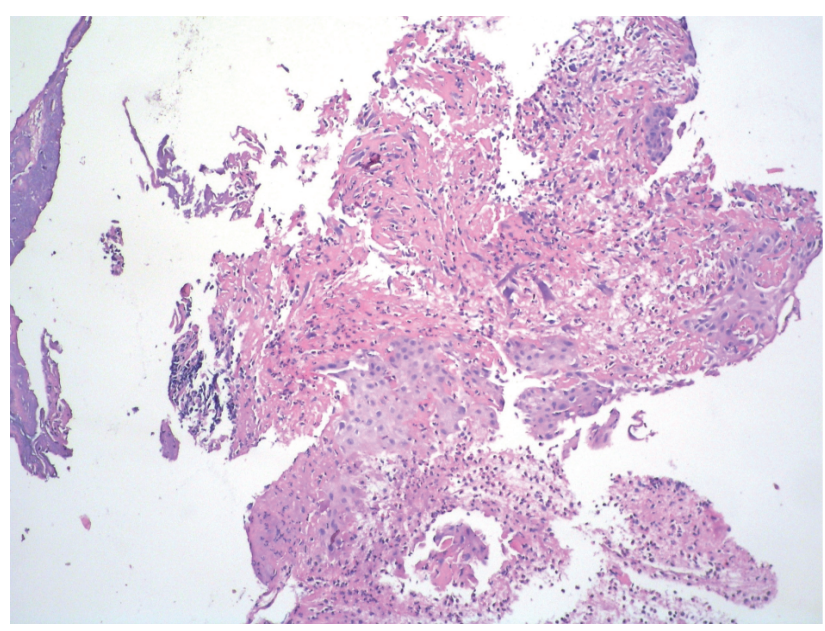

Figure 12. HE, 40X. Tumour tissue nests with squamous cell carcinoma pattern. Endobronchial forceps biopsy.

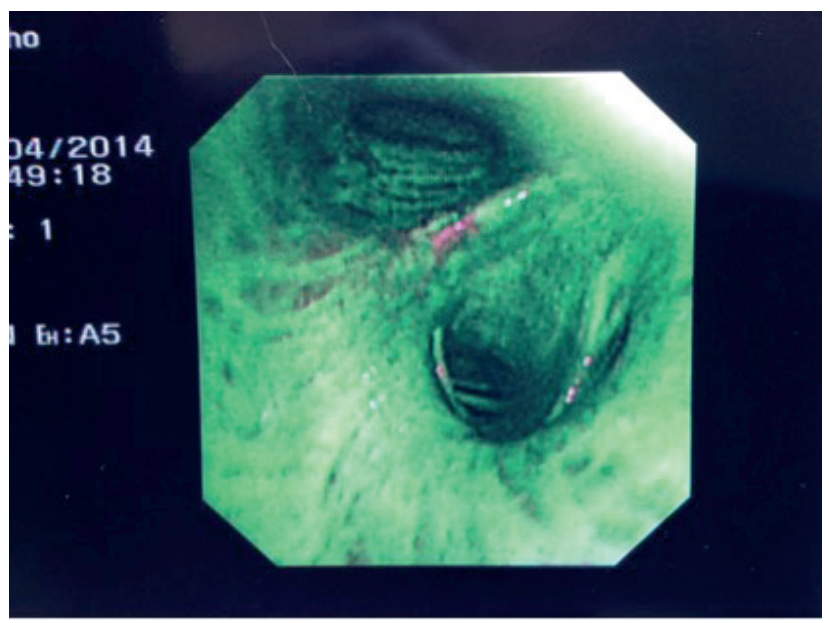

Figure 13. Autofluorescence bronchoscopy. Suspected lesion on the eperon of middle lobe bronchus.

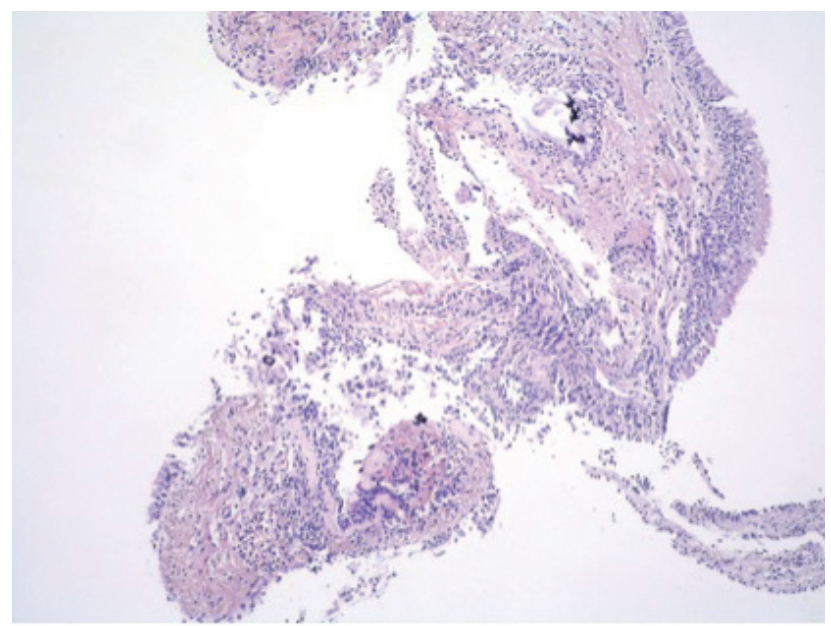

Figure 14. HE, 40X. Bronchial mucosa with epithelial hyperplasia and chronic inflammatory infiltrates. Endobronchial forceps biopsy. 


\section{DISCUSSION}

As a rule, the prognosis of carcinoma in situ 0 stage is excellent, especially in comparison with the results of the other stages of lung cancer (74 - 91\% 5-year survival rate). ${ }^{1}$ The classification of premalignant lesions ${ }^{2}$ is shown in Table 1. It can be seen that the mucosa has to go through certain changes before reaching the critical point that we are discussing. There are different opinions especially on this point. P. George et al. think that treatment should be postponed while the radiological and histological approvals for progression to invasive carcinoma emerge. ${ }^{3}$ Others conclude that the key point is appearance of angiogenesis, which expresses the change of the lesion from intraepithelial to submucosal. ${ }^{4}$ Then a change in the color of the mucosa in autofluorescence bronchoscopy takes place. As a comparison, only $29 \%$ of CISs have been discovered by white light bronchoscopy. ${ }^{5}$

In the first case we applied only endobronchial treatment, one session and a few bronchoscopies. Furthermore, the patient denied open surgery. Such an approach is applied routinely by different authors, but the most prominent center is T. Sutedjas's in Amsterdam. ${ }^{6}$ Other authors speculate with the place of CIS placing it together with moderate and high grade dysplasia in the group of preinvasive lesions. ${ }^{7}$ There is an opinion that this group of changes can progress spontaneously and regress also. ${ }^{8}$ The autofluorescence bronchoscopy was used to follow up the patient's scar (Fig. 4).

In the second case open surgery was applied and probably this was the best approach because

Table 1. Classification of endobronchial premalignant lesions according to World Health Organization. ${ }^{9}$

\begin{tabular}{ll}
\hline & \multicolumn{1}{c}{ Histology } \\
\hline A & Normal mucosa \\
B & Inflammation / Bronchitis \\
C & Hyperplasia \\
D & Squamous metaplasia \\
E & Low grade dysplasia \\
F & Moderate dysplasia \\
G & High grade dysplasia \\
H & Carcinoma in situ \\
L & Invasive carcinoma \\
\hline
\end{tabular}

the histological result from the surgery specimen showed invasion of submucosa. In these cases, definitely the surgery has advantages to use..$^{10,11}$

In the third case, the healing was an accidental case by extraction of the tumor along with the forceps biopsy. A similar case was described by R. Snyder. ${ }^{12}$ Here the control bronchoscopy was done in an autofluorescence mode (Fig. 14). In this regard the latter has advantages for treating CIS lesions than white light bronchoscopy.

\section{CONFLICT OF INTEREST}

The authors declare no conflict of interest.

\section{REFERENCES}

1. Edell E, Lam S, Pass H, et al. Detection and localization of intraepithelial neoplasia and invasive carcinoma using fluorescence-reflectance Bronchoscopy: An International Multicenter Clinical Trial. J Thorac Oncol 2009;4(1):49-54.

2. Holiday D, McLarty J, Farley M, et al. Sputum cytology within and across laboratories. A reliability study. Acta Cytol 1995;39:195-206.

3. George PJ, Banerjee AK, Read CR, et al. Surveillance for the detection of early lung cancer in patients with bronchial dysplasia. Thorax 2007;62:43-50.

4. Kennedy TC, Lam S, Hirsch FR. Review of recent advances in fluorescence bronchoscopy in early localization of central airway lung cancer. The Oncologist 2001;6:257-62.

5. Jang TW, Oak CH, Chun BK, et al. Detection of pre-invasive endobronchial tumors with D-light/ autofluorescence system. J Korean Med Sci 2006; 21:242-6.

6. Daniels JM, Sutedja TG. Detection and minimally invasive treatment of early squamous lung cancer. Ther Adv Med Oncol 2013;5(4):235-48.

7. Häußinger K, Becker H, Stanzel F, et al. Autofluorescence bronchoscopy with white light bronchoscopy compared with white light bronchoscopy alone for the detection of precancerous lesions: a European randomised controlled multicentre trial. Thorax 2005;60:496-503.

8. Bota S, Auliac JB, Paris C, et al. Follow-up of bronchial precancerous lesions and carcinoma in situ using fluorescence endoscopy. Am J Respir Crit Care Med 2000;164:1688-93.

9. Lee P, van den Berg RM, Lam S, et al. Color fluorescence ratio for detection of bronchial dysplasia and carcinoma in situ. Clin Cancer Res 2009;15:4700-5.

10. Venmans B, van Boxem A, Smit E, et al. Outcome of bronchial carcinoma in-situ. Chest 2000;117:1572-6.

11. Sato M, Saito Y, Endo C, et al. The natural history of radiographically occult bronchogenic squamous cell 
carcinoma: a retrospective study of overdiagnosis bias. Chest 2004;126:108-13.
12. Snyder RW, Mishel HS, Christensen GC. Bronchogenic carcinoma in situ on the carina eradicated by endobronchial biopsy. Chest 1990;98:1516-17.

\title{
Диагноз и лечение трёх случаев бронхиалной карциномы in situ
}

\author{
Валери Й. Андреев ${ }^{1}$, Николая А. Янев ${ }^{1}$, Стефан К. Станимиров ${ }^{1}$, Теменужка В. Мирчева², \\ Иван Н. Иванов ${ }^{2}$, Савелина Поповска ${ }^{2}$, Петкана А. Христова ${ }^{3}$, Явор Й. Иванов ${ }^{1}$ \\ ${ }^{1}$ Клиника пневмологии и фтизиатрии, Университетская больница “Д-р Г. Странски” Плевен ЕАО, Плевен, Болгария \\ 2 Кафедра патологоанатомии, Университетская больница “Д-р Г. Странски" Плевен ЕАО, Плевен, Болгария \\ ${ }^{3}$ Кафедра социальной и превентивной медицины, медицинской статистики, педагогики и психологии, Медицинский \\ университет - Плевен, Плевен, Болгария
}

Адрес для корреспонденции: Явор Й. Иванов, Клиника пневмологии и фтизиатрии , Университетская больница "Д-р Г. Странски" Плевен ЕАО, ул. „Иван Вазов" № 91, Плевен, Болгария E mail: pulmovan@gmail.com Tel: +359887740377

Дата получения: 29 декабря 2016

Дата приемки: 30 мая 2017

Дата онлайн публикации: 23 июня 2017

Дата публикации: 30 марта

2018

Ключевые слова: автофлуоресцентная бронхоскопия, карцинома in situ

\section{Образец цитирования:}

Andreev VY, Yanev NA, Stanimirov SK, Mircheva TV, Ivanov IN Po-povska S, Hristova PA, Ivanov YY. Diagnosis and treatment of three cases of bronchial carcinoma in situ. Folia Med (Plovdiv) 2018;60(1):164-9.

doi: 10.1515/folmed-2017-0062
В качестве части ретроспективного исследования случаев бронхоскопии с автофлуоресцентной бронхоскопией, проведённого в клинике пневмологии и фтизиатрии при Университетской больнице - Плевен, нами обнаружены 3 случая диагностированной карциномы in situ. Лечение было проведено разными способами - с применением эндобронхиальной электрокоагуляции, щипцовой биопсии и открытой хирургии, но с одинаковым при всех случаях результатом - клиническим излечением. Данная статья представляет все три клинических случая и анализ лечения. 